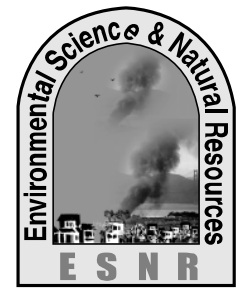

J. Environ. Sci. \& Natural Resources, 7(2): 25-30, 2014 ISSN 1999-7361

\title{
Effect of Gamma Radiation on Morpho-Physiological Characters of Soybean
}

\author{
S. Sarker ${ }^{1}$, M. S. Rahman ${ }^{2}$, M. R. Islam ${ }^{3}$, S. Hasna ${ }^{3}$ and M. S. Islam ${ }^{4}$
}

${ }^{1}$ Bangladesh Agricultural Research Institute (BARI), Akbarpur, Moulvibazar

${ }^{2}$ Department of Crop Botany, Bangladesh Agricultural University, Mymensingh

${ }^{3}$ Bangladesh Agricultural Research Institute (BARI), Rahmatpur, Barisal

${ }^{4}$ Accelerating Agricultural Productivity Improvement (APPI),

International Fertilizer Development Center (IFDC), Faridpur

\begin{abstract}
An experiment was carried out at the experimental farm of Bangladesh Institute of Nuclear Agriculture (BINA), Mymensingh during the period from January, 2011 to April, 2011. The study was conducted to evaluate the effect of gamma radiation on morpho-physiological characters of BARI soybean. Four levels of gamma irradiation viz. 200, 300, 400 and 500 Gy $\gamma$-ray from 60C source and control were irradiated on assigned two genotypes viz. BARI soybean 5 and BARI soybean 6 . Data for growth analyses were collected at different days after sowing. Results revealed that the soybean varieties and gamma irradiation significantly affected morpho-physiological characters where BARI soybean 5 and 200 Gy $\gamma$-ray levels produced the greater results alone or combinations. This combination produced the tallest plant $(37.42 \mathrm{~cm})$, maximum leaf and branch plant $^{-1}(23.15$ and 2.10) at 75 DAS. 200 Gy $\gamma$-ray irradiated plants of BARI soybean 5 produced the highest seed yield (2373.70 $\mathrm{kg}$ ha-1) followed by control treatment $(1887.90 \mathrm{~kg}$ ha-1) at the same variety. On the other hand, the plants consequential from 500 Gy $\gamma$-ray radiated of BARI soybean 5 had shown the lowest seed yield (1050.70 kg ha-1). This result indicating that irradiation significantly decreased on seed yield with increasing doses of gamma rays. So, the variety BARI soybean 5 and 200 Gy $\gamma$-ray alone or combination had outstanding superiority for plant growth over the other gamma ray levels.
\end{abstract}

Key words: Gamma radiation, Growth, Soybean

\section{Introduction}

Soybean (Glycine max L. Merill) is an important and well recognized oil seed and grain legume crop of the world. It belongs to the family Leguminosae and sub-family Papilionaceae. It is highly valuable crop in agriculture, which provides high quantity plant protein and vegetable oils. It was introduced in Bangladesh in around 1942, but its cultivation was started in late seventies as coordinated soybean research project, which was functioning from 19751980 for its improvement and promotional activities of soybean. The cultivation of soybean in Bangladesh (mainly in Noakhali and Feni) started in 1978. Soybean is called the "Golden bean" or "Miracle bean" or "Protein hope of future" because of its high nutritive value. Soybean (Glycine max L.) is a major food and feed source that mainly cultivated for oil and protein (Napoles et al., 2009). Per 100g soybean seed contains about 40-45g protein, $20 \mathrm{~g}$ oil, $20-25 \mathrm{~g}$ carbohydrate, $11.50 \mathrm{mg}$ iron, $208.0 \mathrm{mg}$ calcium and 432 calories energy (Rahman, 2001). About 60\% of the world supply of vegetable protein and $30 \%$ of the oil are provided by soybean (Fehr, 1989). For these reasons, soybean had been recognized as one of the premier agricultural crops of the world (Kaul and Das, 1986). Mutation breeding in crop plants is an effective tool used in mutation breeding to promote gene recombination and mutation frequency (Khundi et al., 1997; Jamil and Khan, 2002; Majeed et al., 2010) especially in crops having narrow genetic base. Low dose of gamma-ray treatment is recommended for the improvement of several plant species (Chen et al., 2010). Ashraf et al. (2003) reported that seedling emergence, panicle fertility and grain yield declined with increasing dose level. Many mutants have been identified as donors of desirable traits in breeding program. Mutation breeding work in soybean crop has yielded in identification of many mutant lines with desirable traits like high germination and survival percent (Rahman et al., 1994). In Bangladesh, gamma radiation techniques has been successfully utilized by BINA, BARI and other some research Institutes. Research reports of gamma radiation effect on growth and yield of soybean genotypes is very limited in Bangladesh. But knowledge of gamma radiation will help to exploit both aerial and edaphic resources of the environment are essential to guide the farmers to maximize the yield of the crop. The objectives of the present study were to select the suitable cultivar that ensures the higher growth and to find out the most advantageous gamma radiation dose in relation to growth characteristics among genotypes of BARI Soybean 5 and BARI Soybean 6.

\section{Materials and Methods}

\section{Experimental site}

The experiment was carried out in the Research Farm of Bangladesh Institute of Nuclear Agriculture (BINA), Mymensingh during the period from January, 2011 to April, 2011. The experimental area is located at $24.6^{\circ} \mathrm{N}$ and $90.5^{\circ} \mathrm{E}$ latitude and at an altitude of $18 \mathrm{~m}$ from the sea level (Khan, 1997).

\section{Experimental materials}

Two genotypes of soybean viz. BARI Soybean- 5 and BARI Soybean- 6 were used as experimental materials for the study. All the genotypes were collected from Bangladesh Agricultural Research Institute (BARI), Joydebpur, Gazipur- 1701.

Soil 
The soil of the experimental area was to the Sonatola soil series of grey flood plain soil under the Agro-ecological Zone (AEZ- 9) and belonged to the Old Brahmaputra Flood Plains Alluvial Tract (UNDP; FAO, 1988). The selected plot was high land, fertile, well drained and having pH 6.7.

\section{Experimental design and layout}

The experiment was laid out in Randomized Complete Block Design (RCBD) with three replications. The whole experimental area was divided into three equal blocks. Each block was then further divided into 10 plots where two soybean varieties were allotted at random according to 5 treatments. Thus there were $30(2 \times 5 \times 3)$ unit plots altogether in the experiment. The size of unit plot was $3 \mathrm{~m} \times 1 \mathrm{~m}$. Row to row and plant to plant distances were 30 and $6 \mathrm{~cm}$, respectively, in each plot.

\section{Land preparation}

Table1. Doses of manure and fertilizers in plots

\begin{tabular}{|c|c|c|}
\hline Manure and fertilizers & Dose $\left(\mathbf{h a}^{-\mathbf{1}}\right)$ & Quantity per plot \\
\hline Cow dung & $6 \mathrm{ton}$ & $3.6 \mathrm{~kg}$ \\
\hline Urea & $40 \mathrm{~kg}$ & $24 \mathrm{gm}$ \\
\hline TSP & $120 \mathrm{~kg}$ & $72 \mathrm{gm}$ \\
\hline MP & $60 \mathrm{~kg}$ & $36 \mathrm{gm}$ \\
\hline Gypsum & $120 \mathrm{~kg}$ & $72 \mathrm{gm}$ \\
\hline
\end{tabular}

\section{Seed sowing}

Seeds of soybean irradiated with five different doses of gamma rays were sown by hand at $3-4 \mathrm{~cm}$ depth. Seeds were sown on $19^{\text {th }}$ January, 2011. Few seedlings were grown in the border of the plots as stock seedling for gap filling subsequently.

\section{Intercultural operations}

\section{a)Thinning out}

Emergence of seedling was completed within 10 days after sowing. Over crowded seedlings were thinned out two times. First thinning was done after 15 days of sowing which is done to remove unhealthy and lineless seedlings. The second thinning was done 10 days after first thinning.

\section{b) Gap filling}

Seedlings were transferred to fill in the gaps where seeds failed to germinate. The gaps were filled in within two weeks after germination of seeds.

\section{c) Weeding}

First weeding was done at 30 DAS and then once a week to keep the plots free from weeds and to keep the soil loose and aerated.

\section{d)Irrigation}

The first irrigation was done after the first weeding after that the irrigation was applied by observing the soil moisture condition. However, each topdressing was followed by irrigation.
The experimental land was first open on $1^{\text {st }}$ January, 2011 with a power tiller. The field was exposed to the sunshine for 7 days prior to the next ploughing. Thereafter, the land was ploughed and crossploughed to obtain good tilth. The plots were spaded one day before planting and the whole amount of fertilizers were incorporated thoroughly before sowing according to fertilizer recommendation guide (BARC, 2012). The soil was treated with insecticides at the time of final ploughing. Insecticides Furadan 5G was used @ 8 $\mathrm{kg} \mathrm{ha}^{-1}$ to protect young plants from the attack of mole cricket, ants, and cutworms.

\section{Manures and fertilizers}

All manures and fertilizers were applied during final plot preparation. The cow dung was applied 15 days ahead of final land preparations. The whole amount of TSP, MP, Gypsum and half of Urea were applied as basal dose at the time of final land preparation. The remaining half of the urea was top dressed in splits at 30 days after sowing (Source: Fertilizer Recommended Guide of BARC 2012). 
Range Test (DMRT) and the significance of difference between pair of means was tested by the Least Significant Differences (LSD) test at $5 \%$ levels of probability (Gomez and Gomez, 1984).

\section{Leaf area plant}

The leaf area was worked out by disc method on dry weight basis at different growth stages as per the procedure suggested by Vivekananda et al. (1972). Twenty five discs of known size were taken through a cork borer from randomly selected leaves of five plants sampled for dry matter distribution. Both the discs and remaining leaf blades was oven dried and the leaf area was calculated by the following formulas and the mean of five plants was expressed in $\mathrm{cm}^{2}$ per plant.

Leaf area $=\frac{\mathrm{Wa} \times \mathrm{A}}{\mathrm{Wd}}$

Where,

$\mathrm{LA}=$ Leaf area $\left(\mathrm{cm}^{2}\right)$

$\mathrm{Wd}=$ Weight of 25 discs in $\mathrm{g}$

$\mathrm{A}=$ Area of 25 discs in $\mathrm{cm}^{2}$.

$\mathrm{Wa}=$ Weight of all the leaves with discs in gram

\section{Crop growth rate (CGR)}

The crop growth rate values at different growth stages were calculated using the following formula$\mathrm{CGR}=\frac{1}{\mathrm{~A}} \cdot \frac{\mathrm{W}_{2}-\mathrm{W} 1}{\mathrm{~T}_{2}-\mathrm{T} 1} \mathrm{~g} \mathrm{~m}^{-2} \mathrm{~d}^{-1}$

Where,

$$
\mathrm{A} \cdot \frac{\mathrm{T}_{2}-\mathrm{T} 1}{\mathrm{~T}}
$$

$\mathrm{W}_{1}=$ Total dry matter production at time initial stage of data recording $\mathrm{T}_{1}(\mathrm{~g})$

$\mathrm{W}_{2}=$ Total dry matter production at final stage of data recording $\mathrm{T}_{2}(\mathrm{~g})$

$\mathrm{A}=$ Ground area $\left(\mathrm{m}^{2}\right)$

\section{Relative growth rate (RGR)}

The relative growth rate (RGR) values at different growth stages were calculated using the following formula-

$$
\mathrm{RGR}=\frac{\log _{e} \mathrm{~W}_{2}-\log _{e} \mathrm{~W} 1}{\mathrm{~T}_{2}-\mathrm{T} 1} \mathrm{~g} \cdot \mathrm{g}^{-1} \mathrm{~d}^{-1}
$$

Where,

$\mathrm{W}_{1}=$ Total dry matter production at time initial stage of data recording $\mathrm{T}_{1}(\mathrm{~g})$
$\mathrm{W}_{2}=$ Total dry matter production at final stage of data recording $\mathrm{T}_{2}(\mathrm{~g})$

\section{Plant height}

\section{Results and Discussion}

Effect of varieties showed significant difference on plant height at all sampling dates but a non significant effect was observed at final harvest time. The combined effect of two varieties and different doses of gamma ray, the tallest plant $(37.42 \mathrm{~cm})$ was found in 200 Gy $\gamma$-ray irradiated plant of BARI soybean 5 at 75 DAS followed $(36.32 \mathrm{~cm})$ by the control treatment at harvest time which was statistically identical. The shortest plant $(27.15 \mathrm{~cm})$ was observed in 500 Gy $\gamma$-ray irradiated plant of BARI soybean 5 (Table 2). Alikamanoglu et al. (2011) also studied that the toxicity of iron, copper, and zinc in soybean seeds of the NE 3297 variety irradiated at different dosages of gamma rays. After cultivating in plastic boxes for 14 days, the average plant heights, fresh weight, and chlorophyll content decreased in inverse proportion to radiation dose.

\section{Number of leaves plant ${ }^{-1}$}

A significant variation was observed for number of leaves plant ${ }^{-1}$ at all DAS due to the main effect of variety and treatments, and also combined effect of both factors. 200 Gy $\gamma$-ray irradiated plants produced the maximum number of leaves plant ${ }^{-1}$ over their all growth periods viz. 30, 45, 60 and 75 days after sowing. But the effect of increasing gamma ray doses on both varieties decreased their morphophysiological traits as well as leaf number whereas, the BARI soybean 5 showed the superior performance in overall explanation. At the variety BARI soybean 5 produced significantly the maximum (23.15) number of leaves plant $^{-1}$ at $200 \mathrm{~Gy} \gamma$-ray irradiated plants at 75 DAS. In contrast, 500 Gy $\gamma$-ray gamma ray irradiated plants of BARI soybean 6 produced the lowest number of leaves plant ${ }^{-1}$ (11.08) compared to BARI soybean 5 (11.23) where they were statistically same (Table 2). Similar trend was also observed at 30, 45 and 60 days after sowing (Table 2).

\begin{tabular}{|c|c|c|c|c|c|c|c|c|c|}
\hline \multirow{2}{*}{ Varieties } & \multirow{2}{*}{$\begin{array}{c}\text { Gamma ray } \\
\text { (Gy } \gamma \text {-ray) }\end{array}$} & \multicolumn{4}{|c|}{ Plant height $(\mathrm{cm})$} & \multicolumn{4}{|c|}{ Number of leaves plant ${ }^{-1}$} \\
\hline & & 30 DAS & 45 DAS & 60 DAS & 75 DAS & 30 DAS & 45 DAS & 60 DAS & 75 DAS \\
\hline \multirow{5}{*}{$\begin{array}{c}\text { BARI } \\
\text { soybean } 5\end{array}$} & Control & $13.53 \mathrm{a}$ & 23.43 & $29.41 \mathrm{~b}$ & 36.32 & $3.28 \mathrm{~b}$ & $8.87 \mathrm{~b}$ & $9.97 \mathrm{bc}$ & $19.58 \mathrm{~b}$ \\
\hline & 200 & $11.20 \mathrm{c}$ & 27.09 & $35.63 a$ & 37.42 & $4.10 \mathrm{a}$ & $10.76 \mathrm{a}$ & $12.35 \mathrm{a}$ & $23.15 \mathrm{a}$ \\
\hline & 300 & $7.73 \mathrm{~d}$ & 19.24 & $25.35 \mathrm{~cd}$ & 28.27 & $3.02 \mathrm{bc}$ & $8.00 \mathrm{~b}$ & $11.45 \mathrm{ab}$ & $15.18 \mathrm{~d}$ \\
\hline & 400 & $4.63 \mathrm{e}$ & 11.43 & $24.27 \mathrm{cde}$ & 29.54 & $2.96 \mathrm{bc}$ & $5.33 \mathrm{~cd}$ & $9.00 \mathrm{cde}$ & $11.79 \mathrm{e}$ \\
\hline & 500 & $4.30 \mathrm{e}$ & 6.76 & $22.81 \mathrm{de}$ & 27.15 & $2.02 \mathrm{~d}$ & $3.77 \mathrm{e}$ & $6.87 f$ & $11.23 \mathrm{e}$ \\
\hline \multirow{5}{*}{$\begin{array}{c}\text { BARI } \\
\text { soybean } 6\end{array}$} & Control & $12.17 \mathrm{ab}$ & 23.97 & $26.09 \mathrm{bcd}$ & 29.97 & $4.43 \mathrm{a}$ & $6.53 c$ & $7.67 \mathrm{def}$ & $16.93 \mathrm{~cd}$ \\
\hline & 200 & $14.43 \mathrm{a}$ & 24.77 & $26.95 \mathrm{bc}$ & 34.03 & $4.57 \mathrm{a}$ & $9.20 \mathrm{~b}$ & $9.33 \mathrm{~cd}$ & $19.56 b$ \\
\hline & 300 & $10.63 \mathrm{c}$ & 19.97 & $22.90 \mathrm{cde}$ & 33.68 & $3.22 \mathrm{~b}$ & $4.83 \mathrm{de}$ & $7.39 \mathrm{ef}$ & $18.49 \mathrm{bc}$ \\
\hline & 400 & $5.57 \mathrm{de}$ & 13.2 & $21.24 \mathrm{e}$ & 32.04 & $2.70 \mathrm{~b}$ & $4.78 \mathrm{de}$ & $6.50 \mathrm{f}$ & $11.30 \mathrm{e}$ \\
\hline & 500 & $4.31 \mathrm{e}$ & 6.24 & $14.98 \mathrm{f}$ & 28.98 & $2.07 \mathrm{~d}$ & $4.43 \mathrm{de}$ & $7.10 \mathrm{f}$ & $11.08 \mathrm{e}$ \\
\hline \multicolumn{2}{|c|}{ LSD } & 2.29 & 2.85 & 3.56 & 6.82 & 0.46 & 1.3 & 1.74 & 2.04 \\
\hline \multicolumn{2}{|c|}{ CV (\%) } & 15.1 & 9.19 & 8.32 & 12.95 & 8.21 & 11.36 & 11.56 & 7.5 \\
\hline \multicolumn{2}{|c|}{ Level of sig. } & $*$ & NS & $*$ & NS & $* *$ & $* *$ & $*$ & $* *$ \\
\hline
\end{tabular}

Table 2. Combined effect of varieties and different gamma rays on plant height at different days after sowing

In a column, figures having similar letter (s) do not differ significantly at $\mathrm{P}<0.05$ as per DMRT

$\mathrm{LSD}=$ Least significant difference; $\mathrm{CV}=$ Coefficient of variance

$* *=1 \%$ level of significance, $*=5 \%$ level of significance and $\mathrm{NS}=$ non significant 


\section{J. Environ. Sci. \& Natural Resources, 7(2): 25-30, 2014 ISSN 1999-7361}

\section{Number of branches plant ${ }^{-1}$}

Genotypic and gamma irradiation effect showed significant difference at all data recording periods but a non significant effect was found at 30 and 45 days after sowing due to the combined effect of varieties and gamma irradiation where they differed significantly at 60 and 75 DAS. Among the combined effect, 200 Gy $\gamma$-ray irradiated plants of BARI soybean 5 gave the maximum number of branches plant ${ }^{-1}$ (2.10) followed by the second highest (1.90) which was found from the untreated plants of BARI soybean 5 at 75 DAS. Similarly, the minimum number of branches plant ${ }^{-1}(1.25)$ was recorded from the 500 Gy $\gamma$-ray irradiated plants of BARI soybean 6 (Table 2).

\section{Leaf dry weight plant ${ }^{-1}$}

Leaf dry weight was significantly affected among the varieties and gamma rays, their combined effect also showed significant at all DAS. Combined effect of varieties and gamma rays, 200 Gy $\gamma$-ray irradiated plants of BARI soybean 5 produced significantly the highest leaf dry weight plant $^{-1}(5.83 \mathrm{~g})$ when $500 \mathrm{~Gy}$ $\gamma$-ray irradiated plants of BARI soybean 6 observed the lowest (3.11g) at 75 DAS (Table 3). Similar results were also found at 30, 45 and 60 DAS (Table 3).

Table 3. Effect of varieties and different doses of gamma radiation on leaf dry weight (g) at different days after sowing

\begin{tabular}{|c|c|c|c|c|c|c|c|c|c|}
\hline \multirow{2}{*}{ Varieties } & \multirow{2}{*}{$\begin{array}{c}\text { Gamma ray } \\
\text { (Gy } \gamma \text {-ray) }\end{array}$} & \multicolumn{4}{|c|}{ Number of branches plant ${ }^{-1}$} & \multicolumn{4}{|c|}{ Leaf dry weight (g) } \\
\hline & & 30 DAS & 45 DAS & 60 DAS & 75 DAS & 30 DAS & 45 DAS & 60 DAS & 75 DAS \\
\hline \multirow{5}{*}{$\begin{array}{c}\text { BARI } \\
\text { soybean } 5\end{array}$} & Control & 1.14 & 1.3 & $1.56 \mathrm{a}$ & $1.90 \mathrm{~b}$ & $0.42 \mathrm{~b}$ & $3.08 \mathrm{a}$ & $3.41 \mathrm{~b}$ & $4.30 \mathrm{~b}$ \\
\hline & 200 & 1.21 & 1.35 & $1.66 \mathrm{a}$ & $2.10 \mathrm{a}$ & $0.57 \mathrm{a}$ & $3.31 \mathrm{a}$ & $3.98 \mathrm{a}$ & $5.83 \mathrm{a}$ \\
\hline & 300 & 1.08 & 1.13 & $1.55 \mathrm{a}$ & $1.62 \mathrm{c}$ & $0.30 \mathrm{c}$ & $2.30 \mathrm{bcd}$ & $3.51 \mathrm{~b}$ & $3.17 \mathrm{~d}$ \\
\hline & 400 & 1.04 & 1.04 & $1.32 \mathrm{~b}$ & $1.86 \mathrm{~b}$ & $0.29 \mathrm{c}$ & $2.02 \mathrm{~d}$ & $3.43 \mathrm{~b}$ & $4.05 \mathrm{~b}$ \\
\hline & 500 & 0.57 & 1.00 & $1.25 \mathrm{~b}$ & $1.41 \mathrm{~d}$ & $0.27 \mathrm{c}$ & $2.05 \mathrm{~d}$ & $3.38 \mathrm{~b}$ & $3.19 \mathrm{~d}$ \\
\hline \multirow{5}{*}{$\begin{array}{c}\text { BARI } \\
\text { soybean } 6\end{array}$} & Control & 1.14 & 1.05 & $1.08 \mathrm{~b}$ & $1.43 \mathrm{~cd}$ & $0.31 \mathrm{c}$ & $2.61 \mathrm{~b}$ & $3.17 \mathrm{c}$ & $4.14 \mathrm{~b}$ \\
\hline & 200 & 1.07 & 1.15 & $1.21 \mathrm{~b}$ & $1.45 \mathrm{~cd}$ & $0.14 \mathrm{~d}$ & $2.43 \mathrm{bc}$ & $2.63 \mathrm{~d}$ & $4.00 \mathrm{bc}$ \\
\hline & 300 & 1.08 & 1.1 & $1.29 \mathrm{~b}$ & $1.43 \mathrm{~cd}$ & $0.14 \mathrm{~d}$ & $2.11 \mathrm{~cd}$ & $2.45 \mathrm{~d}$ & $3.49 \mathrm{~cd}$ \\
\hline & 400 & 0.91 & 0.92 & $1.26 \mathrm{~b}$ & $1.30 \mathrm{~d}$ & $0.27 \mathrm{c}$ & $2.10 \mathrm{~d}$ & $2.51 \mathrm{~cd}$ & $3.49 \mathrm{~cd}$ \\
\hline & 500 & 0.68 & 0.78 & $1.08 \mathrm{~b}$ & $1.25 \mathrm{~d}$ & $0.13 \mathrm{~d}$ & $2.01 \mathrm{~d}$ & $2.43 \mathrm{~d}$ & $3.11 \mathrm{~d}$ \\
\hline \multicolumn{2}{|c|}{ LSD } & 0.16 & 0.15 & 0.21 & 0.2 & 0.052 & 0.284 & 0.156 & 0.487 \\
\hline \multicolumn{2}{|c|}{ CV (\%) } & 9.72 & 8.11 & 9.23 & 7.31 & 4.56 & 8.25 & 4.25 & 7.45 \\
\hline \multicolumn{2}{|c|}{ Level of sig. } & NS & NS & $*$ & $* *$ & $* *$ & $* *$ & $* *$ & $* *$ \\
\hline
\end{tabular}

In a column, figures having similar letter ( $\mathrm{s}$ ) do not differ significantly at $\mathrm{P}<0.05$ as per DMRT LSD = Least significant difference $\mathrm{CV}=$ Coefficient of variance

$* *=1 \%$ level of significance, $*=5 \%$ level of significance and $\mathrm{NS}=$ non significant

Table 3. Effect of varieties and different doses of gamma radiation on total dry matter at different days after sowing

\begin{tabular}{|c|c|c|c|c|c|c|c|c|c|}
\hline \multirow{2}{*}{ Varieties } & \multirow{2}{*}{$\begin{array}{c}\text { Gamma ray } \\
\text { (Gy } \gamma \text {-ray) }\end{array}$} & \multicolumn{4}{|c|}{ Stem dry weight (g) } & \multicolumn{4}{|c|}{ Total dry matter (g) } \\
\hline & & 30 DAS & 45 DAS & 60 DAS & 75 DAS & 30 DAS & 45 DAS & 60 DAS & 75 DAS \\
\hline \multirow{5}{*}{$\begin{array}{c}\text { BARI } \\
\text { soybean } 5\end{array}$} & Control & $0.47 \mathrm{~b}$ & $4.33 \mathrm{~b}$ & $5.64 \mathrm{~b}$ & $7.17 \mathrm{~b}$ & $0.89 \mathrm{~b}$ & $7.41 \mathrm{~b}$ & $9.05 b$ & $11.47 \mathrm{~b}$ \\
\hline & 200 & $0.65 a$ & $5.28 \mathrm{a}$ & $6.39 a$ & $8.29 a$ & $1.23 \mathrm{a}$ & $8.59 a$ & $10.37 \mathrm{a}$ & $14.12 \mathrm{a}$ \\
\hline & 300 & $0.40 \mathrm{c}$ & $3.53 \mathrm{~cd}$ & $4.76 \mathrm{~d}$ & $5.97 \mathrm{~d}$ & $0.70 \mathrm{c}$ & $5.83 \mathrm{~d}$ & $8.27 b c$ & 9.14de \\
\hline & 400 & $0.23 \mathrm{~d}$ & $3.11 \mathrm{~d}$ & $4.37 \mathrm{~d}$ & 5.70de & $0.53 \mathrm{~d}$ & $5.13 \mathrm{e}$ & $7.80 \mathrm{c}$ & $9.75 \mathrm{~cd}$ \\
\hline & 500 & $0.21 \mathrm{~d}$ & $3.08 \mathrm{~d}$ & $4.31 \mathrm{~d}$ & $5.65 \mathrm{de}$ & $0.48 \mathrm{~d}$ & $5.13 \mathrm{e}$ & $7.69 \mathrm{c}$ & $8.84 \mathrm{e}$ \\
\hline \multirow{5}{*}{$\begin{array}{c}\text { BARI } \\
\text { soybean } 6\end{array}$} & Control & $0.34 \mathrm{c}$ & $3.39 \mathrm{~cd}$ & $5.13 \mathrm{c}$ & $6.24 c$ & $0.65 d$ & $6.00 \mathrm{~d}$ & $8.31 \mathrm{bc}$ & $10.38 \mathrm{c}$ \\
\hline & 200 & $0.21 \mathrm{~d}$ & $4.21 \mathrm{~b}$ & $4.59 \mathrm{~d}$ & $5.53 \mathrm{e}$ & $0.35 \mathrm{~d}$ & $6.64 \mathrm{c}$ & $7.21 \mathrm{~cd}$ & $9.53 \mathrm{cde}$ \\
\hline & 300 & $0.24 \mathrm{~d}$ & $3.14 \mathrm{~d}$ & $3.77 \mathrm{e}$ & $5.51 \mathrm{e}$ & $0.38 \mathrm{~d}$ & $5.25 \mathrm{e}$ & $6.22 \mathrm{de}$ & 9.00de \\
\hline & 400 & $0.24 \mathrm{~d}$ & $3.05 \mathrm{~d}$ & $3.46 \mathrm{e}$ & $5.30 \mathrm{e}$ & $0.51 \mathrm{~d}$ & $5.15 \mathrm{e}$ & $5.97 \mathrm{e}$ & $8.79 \mathrm{e}$ \\
\hline & 500 & $0.19 \mathrm{~d}$ & $3.03 \mathrm{~d}$ & $3.41 \mathrm{e}$ & $5.27 \mathrm{e}$ & $0.32 \mathrm{~d}$ & $5.04 \mathrm{e}$ & $5.84 \mathrm{e}$ & $8.38 \mathrm{e}$ \\
\hline \multicolumn{2}{|c|}{ LSD } & 0.073 & 0.344 & 1.185 & 0.467 & 0.116 & 0.415 & 1.175 & 0.784 \\
\hline \multicolumn{2}{|c|}{ CV (\%) } & 7.24 & 4.56 & 6.25 & 4.51 & 5.33 & 8.69 & 7.24 & 6.35 \\
\hline \multicolumn{2}{|c|}{ Level of sig. } & $* *$ & $* *$ & $* *$ & $* *$ & $* *$ & $* *$ & $*$ & $* *$ \\
\hline
\end{tabular}

In a column, figures having similar letter ( $s$ ) do not differ significantly at $\mathrm{P}<0.05$ as per DMRT $\mathrm{LSD}=$ Least significant difference; $\mathrm{CV}=$ Coefficient of variance

$* *=1 \%$ level of significance, $*=5 \%$ level of significance and NS= non significant 


\section{J. Environ. Sci. \& Natural Resources, 7(2): 25-30, 2014 ISSN 1999-7361}

\section{Stem dry weight plant ${ }^{-1}$}

Combined effect of variety, gamma rays on stem dry weight showed significant differences at 30,45 , 60 and 75 DAS. Stem dry weight had higher $(8.29 \mathrm{~g})$ in $200 \mathrm{~Gy} \gamma$-ray irradiated plants of BARI soybean 5 followed by the second highest $(7.17 \mathrm{~g})$ which was observed by untreated plants of the same variety. In contrast, significantly the lowest stem dry weight $(5.27 \mathrm{~g})$ was recorded by 500 Gy $\gamma$-ray irradiated plants of BARI soybean 6 (Table 3).

\section{Total dry matter (TDM)}

Total dry matter was significantly affected due to the effect of variety, gamma rays and their combinations at different days after sowing. Among the treatment combinations, 200 Gy $\gamma$-ray irradiated plants of BARI soybean 5 produced significantly the highest TDM (14.12g) when 500 Gy $\gamma$-ray irradiated plants of BARI soybean 6 observed the lowest TDM $(8.38 \mathrm{~g})$ at 75 DAS (Table 3). Similarly, 200 Gy $\gamma$ ray irradiated plants of BARI soybean 5 produced the higher TDM at 30, 45 and 60 DAS (Table 3).

\section{Crop growth rate (CGR)}

Main effect of variety and gamma rays were significantly affected in respect of CGR whereas their combinations were also significant at 45 and 60 DAS but 75 DAS was insignificant. CGR also had higher $\left(0.49 \mathrm{~g}^{-1} \mathrm{day}^{-1}\right)$ in 200 Gy $\gamma$-ray irradiated plants of BARI soybean 5 followed by the untreated plants of BARI soybean $5\left(43 \mathrm{~g}^{-1}\right.$ day $\left.^{-1}\right)$ and $200 \mathrm{~Gy}$ $\gamma$-ray gamma ray irradiated plants of at BARI soybean $6\left(0.42 \mathrm{~g}^{-1} \mathrm{day}^{-1}\right)$ which was observed the second and third highest, respectively. In contrast, significantly the lowest CGR $\left(0.29 \mathrm{~g}^{-1}\right.$ day $\left.^{-1}\right)$ was recorded by $500 \mathrm{~Gy} \gamma$-ray irradiated plants of BARI soybean 5 (Table 4).

\section{Relative growth rate (RGR)}

Combined effect of variety and gamma rays showed insignificant at 60 and 75 DAS but at 45 DAS was significant. Among the combined effect, RGR had higher $\left(0.058 \mathrm{~g}^{-1}\right.$ day $\left.^{-1}\right)$ in 200 Gy $\gamma$-ray irradiated plants of BARI soybean 5 followed by the untreated plants of BARI soybean $5\left(0.054 \mathrm{~g}^{-1} \mathrm{day}^{-1}\right)$ and 200 Gy $\gamma$-ray gamma ray irradiated plants of at BARI soybean $6\left(0.053 \mathrm{~g}^{-1} \mathrm{day}^{-1}\right)$ at 45 DAS. In contrast, the lowest RGR $\left(0.039 \mathrm{~g}^{-1} \mathrm{day}^{-1}\right)$ was recorded by 500 Gy $\gamma$-ray irradiated plants of BARI soybean 5 (Table 4). All the treatment combinations between varieties and gamma rays were statistically same at 60 and 75 DAS due to its insignificant effect (Table 4).

\section{Seed yield \\ Combined effect of varieties and gamma rays on seed yield showed significant. The result of seed yield decrease with the increasing doses of gamma ray with BARI soybean 6 but BARI soybean 5 decreases up to $400 \mathrm{~Gy} \gamma$-ray as shown in table 4. Two hundred Gy $\gamma$ - ray irradiated plants of BARI soybean 5 produced the highest seed yield $\left(2373.70 \mathrm{~kg} \mathrm{ha}^{-1}\right)$ followed by control treatment $\left(1887.90 \mathrm{~kg} \mathrm{ha}^{-1}\right)$ at the same variety. On the other hand, the plants consequential from 500 Gy $\gamma$-ray radiated of BARI soybean 5 had shown the lowest seed yield $\left(1050.70 \mathrm{~kg} \mathrm{ha}^{-1}\right)$. This result indicating that irradiation significantly decreased on seed yield with increasing doses of gamma rays. Yamashita et al. (1986) also reported that the selected mutants from gamma irradiated soybean. The mutant lines proved early maturity and dwarf stature till $\mathrm{M}_{9}$. The grain sizes of mutants were comparable to the parent and were selected for high yield.}

Table 4. Effect of varieties and different doses of gamma radiation on crop growth rate and relative growth rate at different days after sowing

\begin{tabular}{|c|c|c|c|c|c|c|c|c|}
\hline \multirow{2}{*}{ Variety } & \multirow{2}{*}{$\begin{array}{c}\text { Gamma ray } \\
\text { (Gy } \gamma \text {-ray) }\end{array}$} & \multicolumn{3}{|c|}{ Crop growth rate (CGR) } & \multicolumn{3}{|c|}{ Relative growth rate (RGR) } & \multirow{2}{*}{$\begin{array}{c}\text { Seed yield } \\
\text { (kg ha-1) }\end{array}$} \\
\hline & & 45 DAS & 60 DAS & 75 DAS & 45 DAS & 60 DAS & 75 DAS & \\
\hline \multirow{5}{*}{$\begin{array}{l}\text { BARI } \\
\text { soybean } \\
5\end{array}$} & Control & $0.43 \mathrm{~b}$ & $0.11 \mathrm{ab}$ & 0.16 & $0.054 \mathrm{~b}$ & 0.009 & 0.024 & $1887.90 \mathrm{~b}$ \\
\hline & 200 & $0.49 \mathrm{a}$ & $0.12 \mathrm{ab}$ & 0.25 & $0.058 \mathrm{a}$ & 0.009 & 0.037 & $2373.70 \mathrm{a}$ \\
\hline & 300 & $0.34 \mathrm{c}$ & $0.16 \mathrm{a}$ & 0.06 & $0.047 \mathrm{~cd}$ & 0.025 & 0.017 & $1544.90 \mathrm{~cd}$ \\
\hline & 400 & $0.31 \mathrm{c}$ & $0.18 \mathrm{a}$ & 0.13 & $0.044 \mathrm{e}$ & 0.028 & 0.015 & $1404.90 \mathrm{de}$ \\
\hline & 500 & $0.30 \mathrm{c}$ & $0.18 \mathrm{a}$ & 0.15 & 0.041 & 0.028 & 0.021 & $1050.70 \mathrm{~g}$ \\
\hline \multirow{5}{*}{$\begin{array}{c}\text { BARI } \\
\text { soybean } \\
6\end{array}$} & Control & $0.36 \mathrm{c}$ & $0.15 \mathrm{a}$ & 0.14 & $0.049 \mathrm{c}$ & 0.022 & 0.019 & $1106.70 \mathrm{fg}$ \\
\hline & 200 & $0.42 \mathrm{~b}$ & $0.04 \mathrm{~b}$ & 0.15 & $0.053 b$ & 0.017 & 0.024 & $1725.50 \mathrm{bc}$ \\
\hline & 300 & $0.32 \mathrm{c}$ & $0.06 \mathrm{~b}$ & 0.19 & $0.046 \mathrm{de}$ & 0.002 & 0.029 & $1369.20 \mathrm{de}$ \\
\hline & 400 & $0.31 \mathrm{c}$ & $0.05 \mathrm{~b}$ & 0.19 & $0.044 \mathrm{e}$ & 0.006 & 0.030 & $1298.50 \mathrm{ef}$ \\
\hline & 500 & $0.29 \mathrm{c}$ & $0.05 \mathrm{~b}$ & 0.17 & $0.039 \mathrm{e}$ & 0.006 & 0.027 & $1256.50 \mathrm{ef}$ \\
\hline \multicolumn{2}{|l|}{ LSD } & 0.016 & 0.073 & 0.104 & 0.016 & 0.016 & 0.023 & 185.92 \\
\hline \multirow{2}{*}{\multicolumn{2}{|c|}{ CV (\%) }} & 6.25 & 5.43 & 5.57 & 6.00 & 12.23 & 10.95 & 8.80 \\
\hline & & $* *$ & $*$ & NS & $* *$ & NS & NS & $* *$ \\
\hline
\end{tabular}

In a column, figures having similar letter (s) do not differ significantly at $\mathrm{P}<0.05$ as per DMRT

LSD = Least significant difference; $\mathrm{CV}=$ Coefficient of variance

$* *=1 \%$ level of significance, $*=5 \%$ level of significance and NS= non significant 


\section{J. Environ. Sci. \& Natural Resources, 7(2): 25-30, 2014 ISSN 1999-7361}

\section{Conclusions}

From the above results, it was observed that the variety BARI soybean 5 and 200 Gy $\gamma$-ray irradiated plants had outstanding dominance on growth and

\section{References}

Alikamanoglu, S.; Yaycili, O. and Sen, A. 2011. Effect of gamma radiation on growth factors, biochemical parameters, and accumulation of trace elements in soybean plants (Glycine max L. Merrill). Biol. Trace Elem Res., 141(1-3): 283-293.

Ashraf, M.; Cheema, A.A.; Rashid, M. and Qamar, Z.U. 2003. Effect of gamma-rays on $\mathrm{M}_{1}$ generation in basmati rice. Pak. J. Bot., 35: 791795.

BARC. 2012. Fertilizer Recommendation Guide. Bangladesh Agril. Res. Council, Farmgate, New Airport Road, Dhaka. p.15

Chen, L.; Yang, H.; Lin, B.; Wang, Y.; Li, W.; Wang, D. and Zhang, F. 2010. Effect of gamma-ray radiation on physiological, morphological characters and chromosome aberrations of minitubes in Solanum tuberosum L. Int. J. Radiation Biol., 86: 791-799.

FAO. 1988. Food and Agriculture Organization. Land resources appraisal of Bangladesh for agricultural development. Rep. 2. Agroecological regions of Bangladesh, UNDP, FAO, Rome. p. 116.

Fehr, W.R. 1989. Soybean in oil crops of the world edited by Robbelen G.R.K. Downey and A. Aghri, Mcgraw Hill publishing company $\mathrm{p}$. 283-300.

Gomez, K.A. and Gomez, A.A. 1984. Statistical Procedures for Agricultural Research. $2^{\text {nd }}$ Edn. John Willey and Sons, New York. pp. 97-411.

Jamil, M. and Khan, U.Q. 2002. Study of genetic variation in yield components of wheat cultivar bukhtwar-92 as induced by $\gamma$ radiation. Asian J. Plant Sci., 1: 579-580.

Kaul, A.K. and Das, M.I. 1986. Oil seed in Bangladesh, Ministry of Agriculture, Dhaka. p. 81-85. yield over other variety and gamma rays. In contrast, 500 Gy $\gamma$-ray had the adverse effect on growth in BARI soybean 6 .

Khan, M.S.K. 1997. Effect of different levels of nitrogen on growth, yield and quality of wheat. MS Thesis, Dept. Agron. Bangladesh Agric. Univ. Mymenisngh. p. 35-38.

Khundi, R.S.; Gill, M.S.; Singh, T.P. and Phul, P.S. 1997. Radiation induced variability for quantitative traits in soybean (Glycine max L. Merril). Euphytica, 25: 211-217.

Majeed, A.; Khan, A.U.R.; Ahmad, H. and Muhammad, Z. 2010. Gamma irradiation effects on some growth parameters of Lepidium sativum L. ARPN J. Agric. Biol. Sci., 5: 39-42.

Napoles, M.C.; Guevara, E.; Montero, F.; Rossi, A. and Ferreira, A. 2009. Role of Bradyrhizobium japonicum induced by genistein on soybean stressed by water deficit. Span J. Agric. Res., 7(3): 665-671.

Rahman, L. 2001. Soybean: The Technology of Production and use in food. Dept. Genetics and Plant Breeding. Bangladesh Agric. Univ. Mymensingh. p. 24.

Rahman, S.M.; Takagi, V.; Kubota, K.; Miyamoto, K. and Kawakita, V. 1994. High oleic acid mutant in soybean induced by X-ray irradiation. Biosci. Biotech. Biochem., 58: 1070-1072.

Russell, D.F. 1986. MSTAT-C computer based data analysis software. Crop and Soil Science Department, Michigan State University, USA.

UNDP, 1988. Land Resources Appraisal of Bangladesh for Agricultural Development. Report 2. Agroecological Regions of Bangladesh. United Nations Development Programme and Food and Agriculture Organization. pp. 212-221.

Yamashita, M.; Kawai, H.; Emota, A. and Nisino, H. 1986. Breeding an early variety of soybean by irradiation of Tanba-Koro. Rep. Sec. Grop. Sci. Breed., 31: 22-25. 